\title{
From Offshoring to Rightshoring: Focus on the Backshoring Phenomenon
}

\author{
Lydia Bals, University of Applied Sciences Mainz, Germany, and Copenhagen Business School, Denmark \\ Anika Daum, University of Applied Sciences Mainz, Germany \\ Wendy Tate, University of Tennessee, USA
}

\section{Is "Backshoring" a New Fad or a Viable Business Option?}

Recently, the news about companies bringing back their formerly offshored products and processes has increased. There are indicators that after 50 years of extensive offshoring, companies are rethinking their strategies and realizing the advantages of onshore production and services. For some companies, offshoring might continue as an appropriate strategy, while for others the disadvantages dominate as offshore locations lengthen their delivery times, increase capital tied up in safety stock, and open up the company to uncontrollable quality issues. Another strengthening factor for the backshoring trend is that the conditions of low-cost and industrialized countries have changed as well. Lately, the former ones have faced increasing wage rates and labor shortages, while the latter ones have been able to employ new technologies to increase their productivity (Imberman, 2013; Tate, 2014; Tate, Ellram, Schoenherr and Petersen, 2014a).

To ensure a common understanding of the terms used in this article: Offshoring refers to the relocation of value chain activities outside of the company's original location of its headquarters (Bals, Jensen, MoellerLarsen, \& Pedersen, 2013) and covers both make or buy alternatives (Jahns, Hartmann \& Bals, 2006). Backshoring concerns the relocation of business processes, production, and services alike, which previously had been moved to an offshore or nearshore location, back to the country of origin (Fratocchi, Mauro, Barbieri, Nassimbeni, \& Zanoni, 2014; Kinkel and Maloca, 2009; Arlbjørn and Mikkelsen, 2014). In other words, backshoring is one specific form of reshoring, which itself is the reversal of offshoring (Gray, Skowronski, Esenduran, Rungtusanatham, 2013). The backshoring term only concerns the physical location, not the ownership of the process, which otherwise would be insourcing vs. outsourcing (Förstl, Kirchoff \& Bals, 2015). Consequently, backshoring is possible in different ownership modes. Outsourced backshoring describes the relocation of business processes from an offshore supplier to an onshore supplier, while in-house backshoring describes the relocation of processes from a subsidiary in a foreign country to a company location in the home country (Förstl et al., 2015).

Actually, the phenomenon of backshoring is not new, with documentation dating back to the 1980s (e.g. Fratocchi et al., 2014). Nevertheless, the coverage of related events in the media as well as political interest have recently increased. According to a study by PwC, the European backshoring rate topped the offshoring one in 2013 as 60\% of the examined companies had backshored products and processes and only $55 \%$ offshored. The main backshoring destinations in Europe are Italy,
Ireland, Germany, and Spain (Za, 2014). In Germany, every fourth to sixth company that has offshored then reshores within the next five years, summing up to 400-700 companies per year (Kinkel, 2014). Simultaneously, offshoring activities are on a record low (Dachs, Ebersberger, Kinkel, \& Waser, 2006). The main industries for reshoring are the production of electrical equipment and components, transport equipment and apparel which sum up to $42 \%$ of all backshoring activities (Tate et al., 2014a; Tate, Ellram, Petersen, \& Schoenherr, 2014b).

Other studies, on the contrary, suggest that the offshoring trend has not yet reached an end, as the volume imported from low-cost countries to the industrialized countries is still rising. Furthermore, the majority of production processes that are backshored are assembly-related, while the value-adding aspect of manufacturing from scratch largely remains offshore (Dachs and Zanker, 2014; Stewart, 2014; Van den Bossche, 2013).

Therefore, it is currently very difficult to state a clear trend, but it can be noted that the backshoring phenomenon is gaining increasing momentum. Questions arise regarding the causes and decision processes that are behind this phenomenon and which of these would warrant further research attention.

\section{Drivers: Why Do Companies Decide to Backshore?}

To understand why backshoring solutions have increased lately, it is first necessary to differentiate the drivers. First of all, backshoring might be a short-term operational measure to correct previous offshore decisions that resulted in less than ideal results for the company, or it could actually be a long-term strategic measure. Currently, 80\% of German backshoring activities are categorized as operative corrections to managerial decisions while $20 \%$ are estimated to be strategic adaptions to environmental conditions (Kinkel, 2014). It is observable that the trend moves away from managerial adaptions to strategic ones (Förstl et al., 2015).

Motivators to engage in offshoring have been extensively studied (e.g. Bals et al., 2013; Lewin, Massini, \& Peeters, 2009; Tate, Ellram, Bals, \& Hartmann, 2009), while those to disengage have not. The decisions to disengage can arise through imperfect information or unpredictability of events which manifest themselves in not reaching anticipated synergies or in problems with the offshore location. These difficulties are often based in the geographical distance, like disruptions of transportation, poor cooperation and misunderstandings due to cultural differences, as well as high control, coordination, and logistics costs (e.g., Larsen, Manning, \& Pedersen, 2013). As an example, the premium kitchen manufacturer Berndes Küche $\mathrm{GmbH}$ backshored its production from 
China to Germany after realizing that the fixed costs of two production locations in China and Germany were too high (Christ, 2012).

Quite often, companies that backshore as a managerial adaptation are following differentiation strategies, promising their customers high quality, innovation and outstanding customer service. After offshoring, they realize that this strategy is not compatible with the offshore location as they face unsatisfied customers due to long lead times and quality issues (Gylling, Heikkilä, Jussila, \& Saarinen, 2015; Van den Bossche, Gupta, Gutierrez, \& Gupta, 2014). Another example for this is the German teddybear maker Steiff, which returned its production from China after facing quality complaints from customers and long delivery times (Förstl et al., 2015). Such issues have also been suggested as main drivers of insourcing recently (Stentoft, Mikkelsen, \& Johnsen, 2015). Martinez-Mora and Merino (2014) revealed in a study about backshoring in the Spanish shoe manufacturing industry that especially companies offering premium products are reshoring processes as such an operational adaption.

On the other hand, backshoring might also be based in the change of external influences making a long-term strategic adaptation necesary. Such changes might be triggered by macroeconomic aspects or by new consumption patterns of customers (Kinkel, 2014). Macroeconomic factors influencing location decisions can be wage rate increases in low-cost countries or the increase of oil prices which have an effect on transport costs. China is an example of a country which has experienced increases of wage rates and ancillary labor costs in the last years. Besides, it has faced shortages in qualified personnel while the tax incentives have been reduced. Simultaneously, the conditions of industrialized countries have been changing as well with labor costs shrinking due to the crisis and increasing productivity through new technologies (Arlbjørn \& Mikkelsen, 2014; Tate et al., 2014a; Van den Bossche et al., 2014). As an example, the German company STOPA Anlagenbau shows that the optimization of an ERP system can lower production costs to an extent that backshoring becomes lucrative (Harzer, 2013).

Furthermore, consumers increasingly require fast deliveries, customized products and high quality. These requirements are not compatible with long transport ways and minimum order quantities in offshore countries (Arlbjørn \& Mikkelsen, 2014; Daum, 2015; Tate et al., 2014a). The example of the Spanish footwear industry shows that especially companies offering products in the low and lower middle price segment are backshoring

Price Segment of Products

Premium$$
\text { (1) }
$$

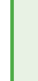

\section{Middle}

Figure 1: Reasons to Backshore per Price Segment (based on Martinez-Mora \& Merino, 2014) as a strategic adaption to changing contextual conditions, as their main reason for offshoring were cost synergies in the first place (MartinezMora \& Merino, 2014). Moreover, this study suggests that the reasons to backshore can actually depend on the price segment of products, as illustrated in Figure 1.

\section{Decision Process: How Do Companies Decide to Backshore?}

While sourcing decision-making processes (e.g., Handley, 2012; Mclvor, 2010) as well as offshoring implementation processes (e.g., Jensen et al., 2013) have been covered in previous literature, reshore decision making has not yet received much attention in the literature. Therefore, this has become one of the further areas studied by the authors (e.g., Förstl et al., 2015; Tate, 2014; Daum, 2015).

As a first step to gain more insight into backshoring decision making, four backshoring cases were analyzed based on the organizational buying center (OBB) literature (Robinson et al., 1967; McQuiston, 1989; Webster and Wind, 1972; Wind and Thomas, 1980). These cases represent three manufacturing relocation and one service relocation events.

In line with the theory (e.g., Robinson et al., 1967), decisions with the importance and complexity of backshoring are usually not taken by one person or department alone but rather by a project team consisting of different departments and backgrounds, the buying center. Within the four case studies, all five participants of the buying center were analyzed: the buyer or person with the formal responsibility for the buying, the decision maker, the user mainly represented by the head of production or internal customers, the influencer, and the gatekeeper who collects and distributes information and therewith has the possibility to filter them (Monczka, Handfield, Giunipero, \& Patterson, 2009; van Weele, 2010). Additionally, one participant classification needed to be added to describe a newly identified group of people: the initiators are those people who are confronted with issues caused by the offshore locations first and push for a solution. Such can be marketing and sales, which realize decreasing sales figures, or finance, which sees the negative financial impacts (Daum, 2015).

Moreover, all involved people in the case study firms were senior managers or owners of the company. This emphasizes the importance of the "shoring" decision. Nevertheless, this importance is not always reflected in the tools used to make this decision. First of all, half of the interviewed companies stated that their final decision was based on a mixture of analyses conducted and an emotional approach. The three analyses that were actually conducted were redesign of processes, cost analyses, and analyses of location factors. Regarding the first, the case study analysis revealed that besides a redesign of the process, often the product itself is being redesigned as well. Regarding the second, total cost approaches were chosen to mainly analyze two aspects: to determine whether backshoring is more 
favorable than offshoring and to determine the best location within the home country. Finally, location factors were mainly examined for availability of skilled personnel and quality of infrastructure. Interestingly, other analyses like scenario planning, risk analysis, or creating a stakeholder matrix were hardly conducted, or not at all (Daum, 2015).

Furthermore, the decision-making process itself with its interactions and influences was analyzed using OBB's four different types of influential forces playing a role in a decision: environmental, organizational, group, and individual forces (van Weele, 2010). All cases suggest that corporate strategy had an influence on the backshoring decision. Companies that follow a differentiation strategy, focusing on innovation, ecological aspects, or quality, might find onshore production and services more suitable than offshore ones. Group forces are observed in the interaction of management or owners with the different stakeholders. In the four cases, not all stakeholders were equally involved, and often actually the users were excluded from decision processes. This re-emphasizes the observation also made by Gylling et al. (2015), who point out that despite the strategic importance of backshoring, the decisions are often solely made on the management level without including the production representatives who might add an important perspective. Also, groups and individuals were indeed found to influence the decision, either through their functional authority or expertise, or acting in selfinterest to drive the decision in the preferred direction. For example, on the individual level a manager of one of the cases drove the location decision to onshore and nearshore countries as in his opinion the company was already over-represented in offshore countries. In another case, a manufacturing expert convinced the company owner of backshoring with his experience and knowledge while in a third case an individual pushed for a certain location in which later on he himself started a new job (Daum, 2015).

With a view towards managerial implications of these preliminary findings, the following can be stated: besides the three evaluations mentioned (redesign of processes, cost analyses, and location factors), the range of analyses seems rather narrow. Especially considering that the majority of companies stated they had faced unexpected delays and difficulties with the relocation, a broader range of analyses, like an exit strategy, change management, or risk analysis might help identifying these risks and preventing them. Furthermore, stakeholder analyses would be sensible in order to follow a holistic approach and include all parties, which might add value to the discussions and decision-making process. Moreover, it might be helpful to offer potential backshoring companies a platform to exchange and discuss knowledge and experiences.

Additional areas of interest to further research in terms of decision making are expanding the use of $\mathrm{OBB}$ as well as exploring further theoretical foundations. Also, current examples often center on SMEs, and the question arises how that decision process looks in multinational companies with multi-location decision-making scenarios (Tate $\&$ Bals, 2014).

\section{Outlook: Which Factors Will Influence the Backshoring Trend in the Near Future?}

Future backshoring decisions will be influenced by factors such as the importance of controlling supply chains, standardization of regula- tions, political incentives, and new technologies. The various trends are summarized in Table 1.

\begin{tabular}{|l|l|}
\hline Level & Trends of Interest \\
\hline Environmental & $\begin{array}{l}\text { Standardization of regulations (e.g. } \\
\text { environmental); political incentives (e.g. } \\
\text { subsidies for backshoring); new technolo- } \\
\text { gies (e.g. 3D printing, Robotic Process } \\
\text { Automation, advancement of cyber-physi- } \\
\text { cal systems for manufacturing automa- } \\
\text { tion) }\end{array}$ \\
\hline Organizational & $\begin{array}{l}\text { Importance of controlling supply chains; } \\
\text { increasing experience with Global } \\
\text { Integrated Shared Services; digitization of } \\
\text { product }\end{array}$ \\
\hline Group and Individual & Increasing use of mobile technologies \\
\hline
\end{tabular}

Table 1: Trends of Interest per Influencing Forces Level

The focus on supply chain capabilities has increased as companies have realized that their supply chains can be a competitive advantage; therefore they increasingly opt to control, own, and shorten them. This allows for the reduction of lead times and the introduction of innovations. Offshoring often means external and long supply chains, which implies the risk of interruptions that have a negative impact not only on profits but also on the customer relationship (Arlbjørn et al. 2014; Ellram et al., 2013). As supply chains can be shortened and centered more around major markets, risks of supply chain disruptions, such as by climatic events like hurricanes and taifuns disrupting transportation (Bals, 2012), decrease. Moreover, more advanced recycling concepts to keep resources in geographical proximity, e.g., in the spirit of closedloop supply chains (e.g., Wells and Seitz, 2005), cradle-to-cradle design (McDonough and Braungart, 2010), and urban mining (Zaman, 2015) would be facilitated.

Another aspect driving reshoring is standardization of regulations. Recently, environmental regulations were proposed as a contributor to reshoring and/or backshoring in particular; for example, international shipping chains often operate on coal, and this could be challenged soon in the context of carbon emissions (Gray et al., 2013). The shortened supply chains mentioned in the previous paragraph would make it easier to overview and steer compliance with environmental as well as social standards, ultimately facilitating implementation of triple bottom line sustainability into whole supply chains (Bals \& Tate, 2015).

Also, backshoring has caught the attention of politicians lately as it promises to create jobs. The impact of governmental incentives on backshoring and its sustainability need to be further researched (Tate, 2014). Nevertheless, it should be kept in mind that while bringing production back closer to today's major markets, future market developments should be carefully considered (Gray et al., 2013). Looking back at the four cases mentioned above, there are only few possibilities for companies to gain information on related opportunitites and risks. The creation of dedicated platforms for tried and tested analyses and exchange among companies making backshoring experiences could help reduce the hurdles and accelerate transitions. 
Finally, technological advances will play a major role in the future production and service landscapes as well. For services, especially Robotic Process Automation (RPA) is of importance. RPA automates service processes and has been reported to shorten them by $60 \%$ and increase their accuracy, which in turn increases customer satisfaction and generates cost savings of 25\%-50\% (IRP, 2015). For physical production processes, additive manufacturing, like 3D printing, and the advancement of cyberphysical systems are of importance. Additive manufacturing enables a highly-automated production of finished products steered by the product itself and therewith makes the assembly of different parts obsolete. Additionally, it enables the digital storage and transportation of products (Lee, Kao, \& Yang, 2014; Abramowicz, 2015; Schmidt, Van den Bossche, \& Lakner, 2014). In Germany, for example, the advancement of cyberphysical systems goes under the headline of "industry 4.0" and is deemed a considerable growth factor for industry within Germany (BMBF, 2014).

The implication of these technologies is that their mastery might in itself develop into a competitive advantage, and in order for companies to enable synergy effects, ensure mainentance, and exert full control, they might be moved to local sites, even if in high(er) wage countries. Having production and service provision back in such locations is facilitiated by the replacement of manual work by automated processes, which in turn erodes wage differentials. This has already led to the notion that the location choice as we know it might be coming to an end, implying that instead of picking a geographical scope, the future will be no specific location at all (e.g., A.T. Kearney, 2014; Brettel, Friederichsen, Keller, \& Rosenberg, 2014). Instead, a network of servers that could be located anywhere in a centralized or decentralized way takes over these tasks.

These technological advances are expected to enable shorter time-tomarket and development cycles as well as more customized products (De Treville et al., 2014). While most coverage on these trends refers to manufacturing, this development applies for physical products as well as services. IT services, for example, have been a target of offshore activities for years, but in the current digital environment, companies increasingly invest in high quality and integrated communication aligned, as this forms an important part of the customer experience (Laudicina, Peterson, \& Gott, 2014).

Although offshore countries still are important locations for Western companies, a trend towards increasing coverage of backshoring events in the media and recent literature is observable. The motives and actual decision-making processes provide interesting research opportunities. Further research should also study more broadly how this trend will develop in the upcoming years and how the off-and reshore movements relate to each other in terms of magnitude. Besides the operational adaptions of those companies for which offshoring was not a suitable strategy in the first place, it is expected that the number of companies for which backshoring is a strategic adaption to face changed macroeconomic factors, regulations, customer demand and supply disruption risks will increase. Backshoring might be a means to secure competitiveness in this changing landscape, harnessing the erosion of traditional geographic criteria in the light of new technological possibilities.

\section{References}

A.T. Kearney. 2014. A Wealth of Choices: From Anywhere on Earth to No Location at All - Back-office services are now embarking on a third wave of arbitrage, as automation becomes simpler, report, 1-12.

Abramowicz, W. (Ed.). 2015. Business Information Systems - 18th International Conference. Heidelberg: Springer.

Arlbjørn, J. S., \& Mikkelsen, O. S. 2014. Backshoring manufacturing: Notes on an important but under-researched theme. Journal of Purchasing and Supply Management, 20(2): 60-62.

Auerbach, C. F., \& Silverstein, L. B. 2003. Qualitative Data - An Introduction to Coding and Analysis. New York: New York University Press.

Bals, L., \& Tate, W. 2014. Implementing Triple Bottom Line Sustainability into Global Supply Chains - call for contributions, Greenleaf Publishing, http://greenleaf-publishing.com/content/TBL_SSCM_FINAL.pdf.

Bals, L. 2012. Climate Change's Impact on Procurement: Risks and Opportunities. In J. Stoner \& C. Wankel (Eds), Managing climate change business risks and consequences: Leadership for global sustainability: 101-119. New York: Palgrave-MacMillan.

Bals, L., \& Jensen, P.O., \& Moeller-Larsen, M., \& Pedersen, T. 2013. Exploring Layers of Complexity in Offshoring Research and Practice. In T. Pedersen, T., L. Bals, P. O. Jensen, \& M. Moeller-Larsen (Eds.), The Offshoring Challenge: Strategic Design and Innovation for Tomorrow's Organization: 1-18, London: Springer.

BMBF. 2014. Bekanntmachung Richtlinien zur Förderung im Themenfeld Industrie 4.0 - Forschung auf den betrieblichen Hallenboden, BAnz AT 30.06.2014 B7: $1-7$.

Brettel, M., Friederichsen, N., Keller, M., \& Rosenberg, M. 2014. How Virtualization, Decentralization and Network Building Change the Manufacturing Landscape: An Industry 4.0 Perspective. International Journal of Mechanical, Aerospace, Industrial and Mechatronics Engineering, 8(1): 37-44.

Christ, F. 2012. Kochgeschirr Berndes: Rückkehr aus China. http://www.dw.com/ de/kochgeschirr-berndes-r\%C3\%BCckkehr-aus-china/av-6700107. Accessed 15 June 2014.

Dachs, B., Ebersberger, B., Kinkel, S., \& Waser, B. R. 2006. Offshoring of production - A European perspective. European Manufacturing Survey. http:// www.isi.fraunhofer.de/isiwAssets/docs/i/de/publikationen/ems2e. pdf. Accessed 18 July 2015.

Dachs, B., \& Zanker, C. 2014. Backshoring of production activities in European Manufacturing. European Manufacturing Survey. http://www.isi. fraunhofer.de/isi-wAssets/docs/i/en/publikationen/EMS-Bulletin-3_ en3.pdf. Accessed 29 September 2015.

Daum, A. 2015. The decision process to backshore: How companies evaluate backshoring potential. Unpublished master thesis, University of Applied Sciences Mainz, Germany.

De Treville, S., Bicer, I., Chavez-Demoulin, V., Hagspiel, V., Schürhoff, N., Tasserit, C., \&Wager, S. 2014. Valuing lead time. Journal of Operations Management, 32(6): 337-346.

Ellram, L. M., Tate, W. L., \& Petersen, K. J. 2013. Offshoring and Reshoring: An Update on the Manufacturing Location Decision. Journal of Supply Chain Management, 49(2): 14-22. 
Förstl, K., Kirchoff, J., \& Bals, L. 2015. Towards a Unified Conceptualization of Reshoring and Insourcing Decisions and Their Drivers, presented at Academy of Management Annual Meeting, Vancouver, Canada. Nominated for AOM Carolyn Dexter (Best International Paper) award 2015.

Fratocchi, L., Di Mauro, C., Barbieri, P., Nassimbeni, G., \& Zanoni, A. 2014. When manufacturing moves back: Concepts and questions. Journal of Purchasing \& Supply Management, 20(2): 54-59.

Gray, H. P. (Ed.) 2003. Extending the Eclectic Paradigm in International Business Essays in Honor of John Dunning. Cheltenham: Edward Elgar.

Gray, J. V., Skowronski, K., Esenduran, G., \& Rungtusanatham, J. M. 2013. The reshoring phenomenon: What supply chain academics ought to know and should do. Journal of Supply Chain Management, 49(2): 27-33.

Gylling, M., Heikkilä, J., Jussila, K., \& Saarinen, M. 2015. Making decisions on offshore outsourcing and backshoring: A case study in the bicycle industry. International Journal of Production Economics, 162(1): 92-100.

Handley, S. M. 2012. The perilous effects of capability loss on outsourcing management and performance. Journal of Operations Management, 30(1): 152-165.

Harzer, C. 2013. Alle Stärken vereint. http://www.industrieanzeiger.de/home/-/ article/12503/15938009/. Accessed 15 June 2015.

Imberman, W. 2013. Reshoring Western Industry. Industrial Management, Sep/ Oct: 25-30.

Institute for Robotic Process Automation. 2015. Benefits or RPA. http://www. irpanetwork.com/benefits-of-rpa/. Accessed 28 June 2015.

Jahns, C., Hartmann, E., \& Bals, L. 2006. Offshoring: dimensions and diffusion of a new business concept. Journal of Purchasing and Supply Management, 12(4): 218-231.

Jensen, P. D. Ø., Larsen, M. M., \& Pedersen, T. 2013. The organizational design of offshoring: Taking stock and moving forward. Journal of International Management, 19(4): 315-323.

Kinkel, S. 2014. Future and impact of backshoring - Some conclusions from 15 years of research on German practices. Journal of Purchasing and Supply Management, 20(2): 63- 65.

Larsen, M. M., Manning, S., \& Pedersen, T. 2013. Uncovering the hidden costs of offshoring: The interplay of complexity, organizational design, and experience. Strategic Management Journal. 34 (5): 533-552.

Laudicina, P., Peterson, E., \& Gott, J. 2014. A Wealth of Choices: From Anywhere on Earth to No Location At All. https://www.atkearney. de/documents/856314/5132494/BIP_A+Wealth+of+Choices. pdf/8fa1d356-f8cf-4aa3-934a-dc54790ba316. Accessed 17 July 2015.

Lee, J., Kao, H.-A., \& Yang, S. 2014. Service Innovation and smart analytics for Industry 4.0 and big data environment. Procedia CIRP, 16(5): 3-8.

Lewin, A. Y., Massini, S. \& Peeters, C. 2009. Why Are Companies Offshoring Innovation? The Emerging Global Race for Talent. Journal of International Business Studies, 40(6): 901-925.

Martínez-Mora, C., \& Merino, F. 2014. Offshoring in the Spanish footwear industry: A return journey? Journal of Purchasing and Supply Management, 20(7): 7-8.

McDonough, W., \& Braungart, M. 2010. Cradle to cradle: Remaking the way we make things. MacMillan.

Mclvor, R. 2010. Global services outsourcing. Cambridge: Cambridge University Press.
Mclvor, R. 2013. Understanding the Manufacturing Location Decision: The Case for the Transaction Cost and Capability Perspectives. Journal of Supply Chain Management, 49(2): 23-26.

Monczka, R. M., Handfield, R. B., Giunipero, L. C., \& Patterson, J. L. 2009. Purchasing and Supply Chain Management (4th edn). Cincinnati, $\mathrm{OH}$ : SouthWestern Cengage Learning.

McQuiston, D. 1989. Novelty, complexity, and importance as causal determinants of industrial buyer behavior. Journal of Marketing, 53(2): 66-79.

Quinlan, C. 2011. Business Research Methods. Hampshire: South-Western Cengage Learning.

Quinn Patton, M. 2015. Qualitative Research \& Evaluation Methods (4th edn). London: Sage.

Robinson, P., Faris, C., \& Wind, Y. 1967. Industrial Buying and Creative Marketing. Boston: Allyn and Bacon.

Schmidt, B., Van den Bossche, P., \& Lakner, M. 2014. New Manufacturing Technologies. http://www.atkearney.de/documents/856314/4640780/ New+Manufacturing+Technologies.pdf/c47cd177-0f2e-4cf2-96f92af5e7443997. Accessed 17 July 2015.

Stentoft, J., Mikkelsen, O. S., \& Johnsen, T. E. 2015. Going Local: A Trend towards Insourcing of Production? Supply Chain Forum: An International Journal, 16(1): 2-13.

Stewart, A. 2014. 2014 A.T. Kearney Reshoring Index: Down 20 Basis Points Yearover-Year From 2013. Uncovers What Manufacturers Are Actually Doing. http://www.atkearney.co.uk/news-media/news-releases/newsrelease/-/asset_publisher/000IL7Jc67KL/content/2014-a-t-kearneyreshoring-index-down-20-basispoints-year-over-year-from2013-uncovers-what-manufacturers-are-actuallydoing/10192?_101_ INSTANCE_000IL7JC67KL_redirect=\%2Fnewsmedia\#sthash. RoZlbFCx.dpuf. Accessed 17 July 2015.

Tate, W. L. 2014. Offshoring and reshoring: U.S. insights and research challenges. Journal of Purchasing and Supply Management, 20(2): 66-68.

Tate, W. L., Ellram, L. M., Schoenherr, T., \& Petersen, K. J. 2014a. Global competitive conditions driving the manufacturing location decision. Business Horizons, 57(3): 381-390.

Tate, W. L., Ellram, L., Bals, L., \& Hartmann, E. 2009. Offshore outsourcing of services: An evolutionary perspective. International Journal of Production Economics, 120(2): 512-524.

Tate, W. L., \& Bals, L. 2014. Outsourcing/Offshoring Insights: Going Beyond Reshoring to Rightshoring — call for papers, International Journal of Physical Distribution \& Logistics Management (IJPDLM), http://www. emeraldgrouppublishing.com/products/journals/call_for_papers. htm?id=5868.

Tate, W. L., Ellram, L. M., Petersen, K. J, \& Schoenherr, T. 2014b. Current Practices in Offshoring and Reshoring. Council of Supply Chain Management Professionals report: 1-71.

Van den Bossche, P. 2013. Re-Shoring: Is it Fab or Fad?. Supply Chain Management Review, 17(6): 46-47.

Van den Bossche, P., Gupta, P., Gutierrez, H., \& Gupta, A. 2014. Solving the Reshoring Dilemma. Supply Chain Management Review, 18(1): 26-33.

Van Weele, A. J. 2010. Purchasing and Supply Chain Management (5th edn). Hampshire: Cengage Learning.

Webster Jr, F. E., \&Wind, Y. 1972. A General Model for Understanding Organizational Buying Behavior. Journal of Marketing, 36(2): 12-19. 
Wells, P., \& Seitz, M. 2005. Business models and closed-loop supply chains: a typology. Supply Chain Man-agement-An International Journal, 10(3-4): 249-251.

Wind, Y., \& Thomas, R. 1980. Conceptual and methodological issues in organisational buying behavior. European Journal of Marketing, 14(5-6): 239-263.

Yin, R. K. 2003. Case Study Reseach - Design and Methods (3rd edn). Applied Social Research Methods Series, Vol. 5. Thousand Oaks, CA: Sage.

Za, V. 2014. The lure of cheap Chinese manufacturing is fading for European companies. http://uk.businessinsider.com/r-euro-zone-companiescome-home-as-asian-costs-rise-2014-12? r=US\&IR=T. Accessed 29 September 2015.

Zaman, A.U. 2015. A comprehensive review of the development of zero waste management: lessons learned and guidelines. Journal of Cleaner Production, 91: 12-25.

Lydia Bals (lydia.bals@hs-mainz.de) is Professor of Supply Chain \& Operations Management in Mainz and a Visiting Professor in Copenhagen. She holds a Doctoral Degree from European Business School in Germany and was a visiting scholar at Wharton and Columbia University in 2008. From 2008-2013 she worked in the industry fulltime in managerial positions, before returning to academia in 2014. Her main research areas are Off- $/$ Reshoring, Sustainable Supply Chain Management, and Procurement Organization. She has published in the Journal of International Management, Journal of Supply Chain Management, Industrial Marketing Management, Journal of Purchasing \& Supply Management, and other academic outlets.

Anika Daum (nika.daum@gmail.com) is currently employed at KPMG AG as a consultant in Finance Advisory. Until September 2015 she studied her Master in International Business at the University of Applied Sciences Mainz, Germany and Assumption University of Thailand. In her master thesis, she conducted case study research about backshoring to examine the backshoring decision process.

Wendy Tate (wendy.tate@utk.edu) is an Associate Professor of Supply Chain Management, Department of Marketing and Supply Chain Management at the University of Tennessee and has a PhD in Supply Chain Management from Arizona State University. She has more than 15 years of practical supply chain experience. Her research focuses primarily on two different types of business problems. First, services purchasing including outsourcing and offshoring, which expanded into "reshoring". The second area is on environmental business practices. She has published research in many top tier academic journals including the Journal of Operations Management, Journal of Supply Chain Management, California Management Review and others. 